\title{
Um novo abolicionismo para a ascensão na nação da Mãe Preta: discursos sobre a fraternidade racial no jornal $O$ Clarim $d a$ Alvorada (1924-1932).
}

\author{
The new abolitionism for a social mobility in the nation of Black \\ Mother: narratives of racial fraternity in the Clarim da Alvorada \\ newspaper (1924-1932)
}

\section{Flávio Thales Ribeiro Francisco ${ }^{1}$}

RESUMO

Neste artigo, trataremos do projeto de inclusão da população negra brasileira concebido nas páginas do jornal O Clarim da Alvorada nas décadas de 1920 e 1930. Esta publicação procurou afirmara ideia de uma nação brasileira "racialmente fraterna" baseada na imagem da Mãe Preta, celebrando uma congregação entre negros, brancos e indígenas e elaborando narrativas históricas que legitimassem o papel do negro enquanto cidadão brasileiro na edificação da "pátria brasileira". Nesse sentido, o periódico defendeu a retomada do um projeto abolicionista inacabado que concretizaria a redenção da "raça negra".

Palavras-chave: Imprensa Negra Paulista. Pós-abolição. Movimento Negro

\section{ABSTRACT}

This articles intends to analyze the project of inclusion for black population conceived in the pages of the O Clarim da Alvorada newspaper, between 1920 and 1930. This periodical claimed for a Brazilian racial fraternity based on the image of Mãe Preta, celebrating a congregation among blacks, whites, and Indians and elaborating historical narratives that legitimated the role of bl acks as citizens in the making of Brazilian nation. Thus, the newspaper advocated for the resumption of the unfinished abolitionist project that would conclude the redemption of "Black race".

Keyword: Paulista Black Press. Post-abolition. Black Movement.

${ }^{1}$ Professor Adjunto do Bacharelado em Ciências Humanas e do Bacharelado em Relações Internacionais da Universidade Federal do ABC. 


\section{O Clarim e o debate em torno das condições do negro no Brasil}

O jornal o Clarim da Alvorada surgiu a partir da intenção de Jaime de Aguiar, então funcionário público, de criar uma folha para a publicação de textos literários de escritores que circulavam entre os espaços da "elite negra" da cidade de São Paulo. Em 1924, com o auxílio de seu amigo José Correia Leite, publicou a primeira edição desse periódico. Até então, a grande maioria dos jornais negros privilegiava as notícias referentes aos eventos festivos, se caracterizando como colunas sociais de um grupo dedicado a estabelecer um estilo de vida alinhado aos códigos e convenções da cultura dominante paulistana (BASTIDE, 1973).

A imprensa negra paulista que se formara nas primeiras décadas do século XX era associada aos grêmios recreativos de um segmento da população negra da cidade aspiranteà ascensão social. Embora vivendo praticamente nas mesmas condições e espaços que as classes populares, esse grupo se formava a partir da criação de laços de solidariedade baseados na elaboração da imagem de um negro moderno, distante das figuras estereotipadas dos negros populares imersos nas culturas tradicionais de influências africanas. As experiências da "elite negra" nos grêmios recreativos eram orientadas pelas ideias de "evolução" e "progresso", que proporcionavam narrativas de modernização do negro paulistano e brasileiro que seguiam as retóricas do Estado de São Paulo como centro de desenvolvimento da nação.

Portanto, esse grupo de negros paulistanos passou a mobilizar elementos que poderiam singularizá-los como um grupo de prestígio e um exemplo a ser seguido pelo resto da população negra da cidade de São Paulo. A maioria dessa "elite" não se distinguia das camadas mais populares no mercado de trabalho que se constituía, mas existiam figuras que haviam experimentado uma relativa ascensão social, fazendo parte, sobretudo, de um funcionalismo público de segunda classe com ocupações como a de auxiliar de bibliotecário, como foi o caso de Jaime de Aguiar. Eles não questionavam a ordem social vigente, assimilando, inclusive, uma ideologia de controle social que racializava os trabalhadores, criando a representação dos negros como indisciplinados e pouco afeitos a uma ética do trabalho (CHALHOUB, 2005; ALBUQUERQUE 2009). O projeto de modernização das lideranças negras visava reelaborar a imagem da população negra no interior dessa própria ordem social que reestruturava as hierarquias raciais no pós-abolição.

Os jornais precursores da imprensa negra paulista, embora privilegiassem as expressões lúdicas dos grêmios recreativos, revelaram os valores da primeira geração de ativistas negros na capital paulista. Entretanto, a ideia de um projeto de ascensão social para a população negra aparece de forma mais clara nos jornais que passaram a publicar artigos de teor combativo sobre as condições sociais da população negra no Brasil. Entre 1915 e 1920, tivemos 
jornais como $O$ Menelik, $A$ Liberdade e $O$ Alfinete que se encarregaram de fazer a cobertura das festividades negras. A partir de 1920, com jornais como o Getulino (1923-1926) de Campinas, o Clarim da Alvorada (1924-1932), o Progresso (1928-1931) e A Voz da Raça (1933-1937), a imprensa negra manifestou de maneira mais clara o seus traços políticos (FERRARA, 1986).

O Clarim da Alvorada, diferentemente da grande maioria dos jornais negros, foi publicado com certa regularidade. Contudo, as receitas do periódico eram limitadas, a redação foi instalada na casa de José Correia Leite e, apesar dos anúncios de fortificantes e escritórios de advocacia, contou basicamente com os recursos dos editores e colaboradores. Durante todo o período de existência do jornal, Aguiar e Leite pensaram em estratégias para criar fontes estáveis, como uma base de assinantes e a transformação do periódico em uma cooperativa. No entanto, o Clarim da Alvorada foi distribuído, na maioria das vezes, de maneira gratuita nos grêmios recreativos. O esforço dos jornalistas do periódico foi o suficiente para garantir uma tiragem média de $2 \mathrm{mil}$ exemplares e edições mensais que variaram entre seis e 12 páginas. O Clarim da Alvorada somente encerrou suas atividades em 1932, quando começou a questionar o autoritarismo das lideranças da Frente Negra Brasileira (1931-1937) e teve a redação empastelada pela milícia da organização negra recém-formada.

No que se refere ao conteúdo, o periódico, embora tenha debutado como uma folha literária, logo manifestou a sua vocação para a articulação de líderes negros na cidade de São Paulo. Os textos que clamavam pela criação de instituições negras que assegurassem a capacitação dos cidadãos negros para a participação em um novo contexto histórico ganharam espaço em suas páginas. Jaime de Aguiar, em um primeiro momento, se restringiu à literatura, mas logo seguiu a lógica de seu colega, José Correia Leite, de discutir o papel central do negro na história do Brasil, problematizando as questões sobre a presença do preconceito de cor e da dificuldade para a integração social do negro.

O conteúdo do debate entre os articulistas do Clarim da Alvorada revela uma abordagem das lideranças negras de viés assimillacionista. Essa primeira geração de ativistas imaginou uma nação brasileira fundamentada na ideia de irmandade entre as "raças", celebrando uma história marcada pelo encontro de negros, brancos e indígenas. O propósito dos jornalistas do periódico não era o de negar a presença das desigualdades sociais, mas de enfrentar os discursos, ainda em voga naquele período, de uma nação brasileira predominantemente branca, utilizando a política de imigração para clarear a sua população.

Nesse sentido, o Clarim da Alvorada se debruçou sobre a história dos negros no Brasil, criando uma linha interpretativa histórica que se iniciava com a chegada dos cativos africanos e se estendia ao período da Primeira República. O período de escravidão, contudo, não foi retratado de maneira negativa. As jornadas de labuta dos escravos nos canaviais, nas minas e em outras atividades econômicas foram consideradas exemplos da participação efetiva dos negros no desenvolvimento econômico do país, ainda que estivessem na base de uma estrutura social extremamente hierarquizada elegitimada juridicamente. Os jornalistas 
fizeram uma interpretação contextualizada no período do pós-abolição, considerando a experiência da escravidão um sinal do comprometimento da população negra com o trabalho. O papel do negro enquanto cativo se contrapunha ao da atual geração que, após a Lei Áurea, perdia o seu espaço em algumas atividades no mercado de trabalho que se formava na cidade de São Paulo (DOMINGUES, 2004). A situação de marginalidade da população negra, associada às imagens estigmatizadas enquanto avessos à labuta, influenciava a visão dos articulistas do Clarim da Alvorada de que os negros não haviam se preparado de maneira adequada para se integrar a um novo contexto social.

Gervásio de Moraes, um dos principais articulistas do periódico, revelou uma visão negativa comum entre as lideranças em relação aos hábitos dos negros populares. Na edição de abril de 1926, ele escreveu um artigo incisivo sobre os males que incidiam sobre a população negra. Para Moraes, os que habitavam os cortiços da cidade, enfraquecidos pelos problemas acarretados pela pobreza, viviam em condições piores do que as do período da escravidão, um quadro social dramático que poderia contribuir para o desaparecimento da população negra:

É esse, sem dúvida, um dos " $x$ " da nossa causa, um mal que está se generalizando assustadoramente, nos ameaçando aniquilar inteiramente, um sulco profundo que a evolução vai deixando para trás, como um episódio negro na nossa existência.

A moderna geração que é a nossa entrou no período agudo de suas remodelações sociais, o seu organismo está enfermado, e, assim como o humano, está reclamando a intervenção de todos quanto se interessam pelo evoluir progressista da moral do nosso povo. (O CLARIM DA ALVORADA, 25 abr. 1926, p, 1-2).

A passagem da escravidão para a o trabalho livre foi tratada como o início do processo de degradação da população negra. Em um primeiro momento, a interpretação foi a de que os trabalhadores negros não compreendiam os códigos que envolviam a ética dos trabalhadores livres, a energia expendida em bebedeiras e eventos festivos regados pelas culturas de influência africana revelava a anomia que os assolava. As lideranças negras se queixavam de que as famílias se perdiam em meio aos prazeres da vida e negligenciavam a importância da instrução como uma possibilidade de ascensão social. A educação, nesse sentido, se apresentava como um instrumento formador e disciplinador dos "negros alienados", um 
elemento que colaboraria para a incorporação de uma nova mentalidade em um novo contexto social.2

Na edição de outubro de 1926, o Clarim da Alvorada publicou um artigo, sem indicação do autor, que discutia a questão da instrução para a população negra. $O$ texto apresentava a cidade de São Paulo como um centro de progresso e evolução social, e como tal, os negros da pauliceia deveriam se educar para acompanhar o ritmo de modernização da cidade. A instrução se tornaria indispensável para o "complemento da grande obra de civismo e patriotismo" no país. As escolas públicas e de algumas associações ofereciam cursos em diversos horários, "mas os estudantes negros não se dedicavam e se esmoreciam com o tempo". O autor, então, clamava pela participação dos negros letrados e chefes de famílias no estímulo da educação entre a população negra da cidade:

Existe nesta capital, um centro de homens de cor, que muito poderia fazer em prol dos nossos, mas para tal fim seria necessário o apoio de todos os nossos patrícios sensatos. Esta agremiação é o Centro Humanitário José do Patrocínio, bem dirigido, com um programa todo cheio de civismo e norteado numa crença, a cultura intelectual e espiritual dos patrícios. Devíamos todos nos alistar ao lado dos esforçados dirigentes dessa agremiação para cooperarmos com o nosso apoio na obra de saneamento da nossa mocidade. (O CLARIM DA ALVORADA, 24 out. 1926, p.2).

As ideias dos articulistas do Clarim da Alvorada sobre a importância da educação entre a população negra estavam em sintonia com aquelas concebidas pelos responsáveis pela organização dos sistemas públicos de educação no Brasil. Nesse período, a "raça" resistia fortemente no imaginário social, orientando o ideal de sociedade a ser conquistado. Ainda que houvesse a tentativa de utilizá-la sem suas propriedades biológicas, ela "explicava e definia" o modo de vida dos negros pobres como exemplo de degradação e os valores que deveriam ser seguidos e difundidos nas práticas escolares propalados por uma elite predominantemente branca. Nesse sentido, a educação não era considerada uma mera instrução, mas uma esfera privilegiada para assimilação de "grupos raciais" que estavam inseridos em práticas culturais supostamente inferiores (DÁVILA, 2006, p. 24-27).

Portanto, a preocupação das lideranças negras era a de criar um plano de mobilidade social para toda a população negra da cidade de São Paulo. A educação se apresentava como

\footnotetext{
${ }^{2} \mathrm{O}$ argumento do negro alienado, em estado de anomia, teria eco na teoria sociológica de Florestan Fernandes (2008), que contou com a colaboração de vários ativistas negros em sua pesquisa, dentre eles o próprio José Correia Leite.
} 
instrumento de ascensão e reelaboração de uma nova imagem do negro paulistano, alinhada ao processo de modernização da cidade e do estado. Porém, a solidariedade "racial" seria fundamental para a aplicação de um projeto de integração do negro à sociedade brasileira. Como observa a historiadora Kim Butler (1998), o Clarim da Alvorada, como elemento integrante do ativismo negro paulistano, privilegiava as estratégias coletivas de mobilidade social em relação às individuais. De acordo com o raciocínio daqueles que se considerava $m$ líderes, a população negra paulistana e do Brasil só alcançaria os níveis mais elevados da sociedade se se organizasse em instituições capazes de educar e aliviar a situação das camadas sociais mais vulneráveis.

\section{A recuperação dos abolicionistas}

Até 1928, a retórica de degradação da população negra predominou nas páginas do periódico negro, sugerindo que as mudanças dependiam muito mais desta do que da sociedade brasileira em geral. Porém, o final da década foi marcado por uma série de incidentes políticos associada à emergência de grupos com diferentes visões ideológicas que questionavam a capacidade do governo republicano de responder às necessidades da população brasileira (ANDREWS, 1998). O Clarim da Alvorada, como representante de lideranças negras também insatisfeitas com a situação, mudou ligeiramente a sua abordagem, culpando as autoridades governamentais pelas condições precárias que assolavam o negro brasileiro, e não a geração pós-abolição.

Em texto publicado na edição de março de 1929, Gervásio de Moraes fez uma crítica ao governo brasileiro que, em suas diferentes gestões, "não se ocupou da situação desigual da grande raça". Se antes ela havia sido "motivo de gargalhadas, agoniada em torniquetes, chicoteada nos troncos ou enxovalhada nas senzalas", após a abolição da escravidão "foi preterida nas suas ambições, nos seus direitos de cidadania". Moraes completou com a acusação da suposta preferência dos brancos brasileiros pelos imigrantes europeus, enchendo uma repartição pública de "moços e moças bonitas" e oferecendo aos "negros brilhantes" os cargos de contínuo ou porteiro. Nesse sentido, a ideia de igualdade entre os indivíduos, indicada na constituição do país, não poderia ser considerada como uma possibilidade para a população negra:

Basta dessa comédia paliativa de que somos um povo amparado e investido pela "Carta Magna". O único amparo que nos é dado é o de 
vivermos afastados dos meios, recusados nos exercícios distintos da sociedade, dominados pela influência dos imigrantes, postos à disposição dos representantes dos poderes nas lutas dos partidos como elementos nas urnas [...] (O CLARIM DA ALVORADA, 3 mar. 1929, p.1).

Parte da crítica do jornal se direcionava para a presença dos imigrantes, que dominavam o mercado de trabalho na cidade de São Paulo. A política de imigração foi considerada um distanciamento dos valores nacionais, pois empurrava os trabalhadores negros para as atividades de menos prestígio(JACINO, 2012). Nesse sentido, o diagnóstico de que a República brasileira não havia se esforçado suficientemente para erguer o negro ao nível de cidadão brasileiro estava associado a um discurso que problematizava a forte presença de imigrantes em São Paulo. Para o Clarim da Alvorada, o negro era uma das figuras que representavam a identidade nacional.

O retrato trágico do período pós-abolição foi confrontado por um passado idílico construído a partir de imagens e figuras históricas, engendrando narrativas patrióticas sobre a participação do negro na economia brasileira. Essa operação, por um lado, se utilizava de discursos e elementos que recriavam uma fraternidade entre brancos e negros no Brasil; por outro, tratava do resgate de um projeto de integração do negro que havia sido supostamente idealizado pelos abolicionistas.

Com a abordagem cada vez mais combativa do Clarim da Alvorada, o clamor pela formação de uma coletividade negra foi acompanhado por uma profusão de símbolos que faziam parte do imaginário das lideranças negras. À medida que os seus jornalistas urgiam pela participação política dos "irmãos de raça", os artigos publicados passavam a explorar cada vez mais as representações que poderiam definir uma identidade para os negros da cidade de São Paulo. Uma das mais usadas pelo jornal foi a dos abolicionistas, dando início a uma narrativa em que estes ocupavam um lugar especial como "redentores da raça". Apropriando-se de figuras históricas, o jornal recuperou determinados aspectos do passado brasileiro que interessavam ao seu projeto político na tentativa de reescrever a história da população negra do Brasil, negociando com a memória coletiva de negros e brancos.

É interessante notar que essa geração do ativismo negro de São Paulo teve uma relação com o abolicionismo distinta das gerações posteriores, sobretudo a que emerge no final da década de 1970. A geração do Movimento Negro Unificado, contrapondo-se ao discurso oficial da democracia racial, desconsiderou a abolição da escravatura como evento transformador para a população negra. Entretanto, nos tempos de circulação e atuação do Clarim da Alvorada, o dia 13 de maio era um feriado celebrado pela maioria dos negros, mantendo assim uma tradição de festas da abolição desde o período da escravidão (PEREIRA, 2011). As datas da Lei 
do Ventre Livre (1871) e da Abolição (1888) eram consideradas festividades cívicas e momentos especiais para uma reflexão sobre a situação dos negros no Brasil:

[A lei do Ventre Livre] Começou a guerra contra a maldita escravidão, em todos os recantos do Brasil surgiram homens, verdadeiros patriotas: João Cordeiro, José do Patrocínio, Ferreira de Menezes, Joaquim Nabuco, Serra e Ferreira de Araujo e outros no centro; José Bonifácio, José Antonio Bento, os ex-escravos Luis Gama e Luis Garcia e outros mais labutaram com verdadeiro amor e carinho pela causa justa.

Portanto, o dia 28 de setembro é para todos os brasileiros o grande dia em que se firmou a formação da verdadeira família brasileira, [o dia para celebrar] aqueles que tanto fizeram com suas lágrimas e sangue para engrandecer a nossa família e torná-la digna ante todas as nações do universo.

Apesar dos pesares, hoje emancipados vivemos. Porém é necessário que pensemos também nos dias futuros, rendemos graças ao Criador, aos emancipadores paladinos fervorosos a quem devemos uma gratidão eterna e a redenção da nossa raça que jamais se extinguirá do coração dos nossos irmãos e filhos do amanhã [...] (O CLARIM DA ALVORADA, 26 set. 1926, p.1).

Sendo assim, nas páginas do Clarim da Alvorada, Luís Gama, José do Patrocínio, Joaquim Nabuco e a Princesa Isabel apareciam ao lado de longas descrições sobre os martírios dos africanos na travessia do Atlântico nos navios negreiros. Na edição de 1928, por exemplo, o jornal publicou o famoso poema de Castro Alves: $O$ navio negreiro. Em quase todos os textos desta edição havia referências ao papel fundamental dos africanos na economia brasileira, trabalhando nas minas, em lavouras e na casa dos senhores:

[...] a adoção da torpe e útil da escravização dos índios e dos negros da África para o cultivo da gleba bárbara e explorar as minas de ouro adormecidas no seio da terra. Os índios, porém, souberam reagir com bravura. Bateram-se denodadamente contra os que lhe usurpavam as terras. Vendo, então, que os índios não se submeteriam, os portugueses lançaram as vistas para a África e de lá trouxeram os pretos que, como já 
se fazia em Portugal, escravizaram e obrigaram ao trabalho das lavouras e da mineração. (O CLARIM DA ALVORADA, 28 set. 1928, p.1).

As edições de comemoração da abolição da escravatura traziam também biografias sumarizadas de alguns abolicionistas. O Clarim da Alvorada demonstrou a sua preferência por José do Patrocínio e Luis Gama. O fato de os dois terem sido negros e importantes ícones do abolicionismo fazia de ambos figuras constantes nas páginas do jornal. Patrocínio e Gama, além de "apóstolos da abolição", seriam exemplos de negros "educados", “dignos", que compreendiam as regras necessárias para ter acesso aos círculos do poder, algo que no olhar dos jornalistas faltava à maioria da população negra. No entanto, podemos afi rmar também que ao destacar Gama e Patrocínio, os jornalistas do Clarim da Alvorada privilegiaram duas figuras marcadas por origens humildes e uma atuação próxima dos populares, diferentemente do "aristocrata" André Rebouças, abolicionista negro também mencionado em alguns textos, mas com uma atuação restrita aos espaços da elite política (JUCÁ, 2001).

Figura 1- imagens de José do Patrocínio e Luís Gama

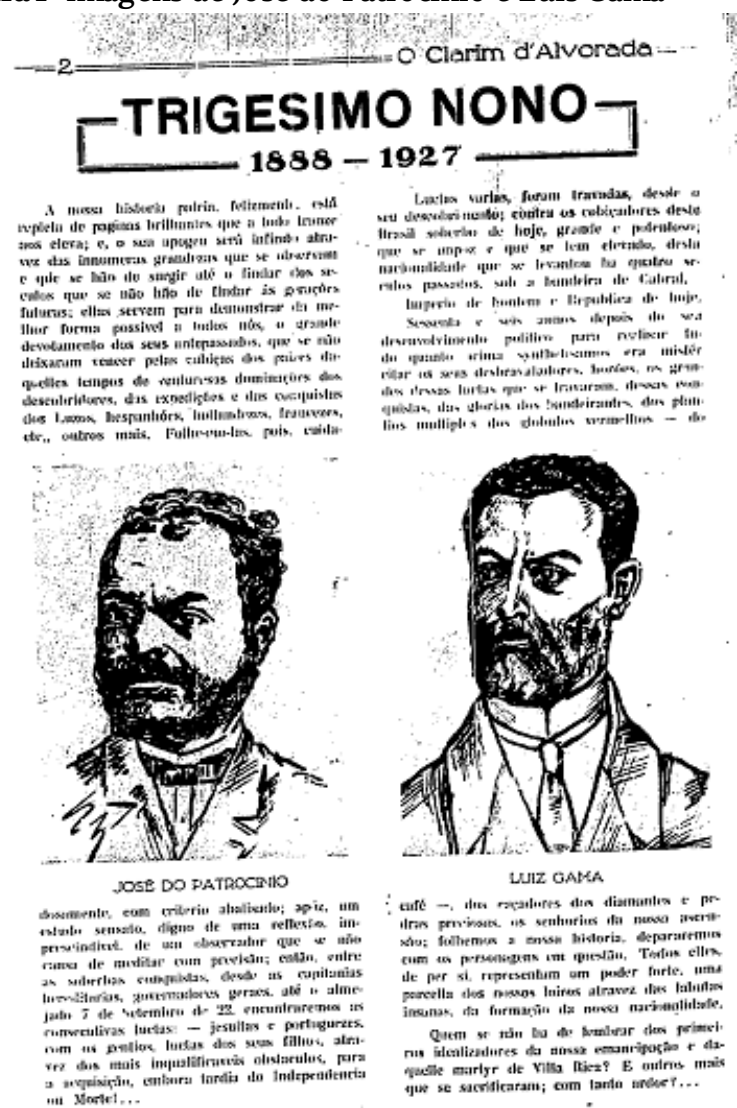

Fonte: Clarim da Alvorada em 13 de maio de 1927. Edição comemorativa da abolição. 
Em maio de 1926, o Clarim da Alvorada trouxe imagens dos dois abolicionistas negros, estampadas em diferentes páginas da edição. $O$ jornal também publicou um artigo de Gervásio de Moraes que, além de tratar dos tempos agonizantes da escravidão, descreveu José do Patrocínio e Luís Gama como umas das figuras "másculas" do movimento abolicionista que, ao lado do "anjo benfeitor" Princesa Izabel, "ruíram os pedestais gigantescos do grande templo escravocrata". Na ótica de Moraes, os abolicionistas haviam aberto o caminho para uma nova luta, que deveria ser retomada pela nova geração:

Sim, já não temos pela frente o espectro hediondo e ameaçador que impunha a chibata; somos, nesta vasta comunhão, crepúsculo que se ergue cheio da mais profunda fé cívica, mas que ofusca indeciso nas brumas do espesso nevoeiro que se levanta desse bloco de gelo com que a maioria tende a impedir o nosso progresso: o preconceito. (O CLARIM DA ALVORADA, 13 maio 1926, p. 3-4).

Já em 1928, José Correia Leite prestou a sua homenagem a Luís Gama, relembrando fatos importantes da biografia do abolicionista. Leite, em seu artigo, enfatizou a atuação de Gama nos tribunais, onde defendeu energicamente e libertou centenas de escravos. Os triunfos do apóstolo da raça foram atribuídos a uma postura guerreira, que obrigou o "paladino" a sacrificar o bem estar de sua família em prol de uma causa maior. O Clarim da Alvorada não apenas celebrava a figura de Luís Gama, também a utilizava como referência de uma luta ainda não encerrada pela inclusão do negro na sociedade brasileira:

No dia 23 de agosto de 1882, perecia na maior pobreza o abnegado Luís Gama, que tinha sacrificado tudo, até mesmo o conforto da família, em prol da libertação dos negros cativos. São Paulo de outrora, aquela São Paulo, pacata na verdade, porém, grande e austera, dentro de sua grandiosa brasilidade, sentiu a perda irreparável do grande mestiço que era naqueles tempos; o ídolo do velho povo paulista, sobretudo, fora o benfeitor dos nossos avós. São Paulo inteiro chorou a morte de Luís Gama e acompanhou o seu corpo até a última morada, e, por muitos anos a memória de Gama nunca foi esquecida. Depois, com o decorrer dos anos, São Paulo foi perdendo a sua velha tradição, e, presentemente, essa data passa quase que desapercebida. Ninguém mais do que nós, os negros do Brasil moderno deverá sentir, compreender e levar em consideração, de uma forma cabal, o valor da passagem desta data que 
tem passado assim, em branca nuvem. O Clarim da Alvorada, que tem procurado fielmente representar os altos sentimentos da raça, apesar do grande desapoio com que vem lutando no seio da mesma, pede hoje, aos negros de São Paulo, aos verdadeiros PALMARINOS DE PIRATININGA que ao menos uma flor singela coloque sobre a lápide do grande Palmarino, que fez de sua vida uma verdadeira página de glórias repassadas de angústia, bondade e rebeldia (O CLARIM DA ALVORDA, 12 ago. 1928, p.1).

Os artigos sobre a escravidão, abolição e a questão do negro no período pós-abolição sugerem, como havíamos observados anteriormente, uma linha histórica que começa na travessia do Atlântico pelo navio negreiro, passa pela participação dos africanos como escravos em atividades fundamentais da economia brasileira e termina com o momento que deveria ser o da redenção do negro no Brasil. O período da abolição, combinado ao da proclamação da República brasileira, foi tratado como o de corrupção e degradação do negro em bebedeiras e promiscuidades. Os tempos do Clarim da Alvorada são, para os editores, aqueles da alienação e apatia negra. O jornal clamava por uma nova geração de apóstolos, assim como haviam sido os honrados "libertadores da raça".

O abolicionismo retratado pelo periódico negro não era compreendido somente como um movimento que lutou pela libertação dos escravos, mas como aquele que abriu as portas para integração do negro à sociedade brasileira. Os "redentores da raça", portanto, ajudaram a inaugurar uma nova ordem social no país que integraria socialmente a população negra, porém os esforços para efetivar a inclusão social não foram seguidos adiante, se perdendo com o passar do tempo. Mesmo que os abolicionistas não tivessem se articulado para criar um projeto amplo de Estado para a transformação do negro em cidadão (MACHADO, 2010; AZEVEDO, 2003), o Clarim da Alvorada descrevia o grupo como coeso e com objetivos bem definidos no que se refere à liberdade e à transformação do negro em trabalhador livre. Nesse sentido, cabia aos jornalistas resgatarem este "projeto" e difundi-lo entre os seus leitores.

O esforço do Clarim da Alvorada para recuperar o passado e estabelecer uma memória abolicionista pode ser verificado através do tratamento do jornal dispensado, até mesmo, aos parentes dos "paladinos da liberdade". No ano de 1929, o periódico negro trouxe in formações sobre os familiares do abolicionista José do Patrocínio. Na edição de janeiro, foi publicada uma nota sobre o movimento da imprensa carioca para um aumento substancial da pensão de Maria Henriqueta Sena - viúva de Patrocínio - que vivia em condições precárias no Rio de Janeiro. A informação era a de que o Senador Celso Bayna havia encaminhado o projeto para o aumento, aguardando o apoio de colegas para que fosse aprovado (O CLARIM DA ALVORADA, 6 jan.1929, p.1). Contudo, o ano foi trágico para os Patrocínios, a edição de agosto publicou uma pequena nota de falecimento de Maria Henrique Sena, o assunto seria tratado de forma 
adequada na edição seguinte, em setembro, mês de comemoração da Lei do Ventre Livre. Já no mês de outubro, foi a vez de José do Patrocínio Filho, rebento do abolicionista, que ganhou destaque na primeira página do Clarim da Alvorada devido à sua morte prematura (O CLARIM DA ALVORADA, 27 out. 1929, p.1).

A recuperação dos abolicionistas foi celebrada também através de romarias pelo centro da cidade de São Paulo. O jornal junto com as lideranças do Centro Cívico Palmares, no dia 13 de maio de 1929, reuniu famílias negras na Praça João Mendes. Segundo o relato, as pessoas presentes no evento ouviram discursos sobre a questão do negro brasileiro e depois caminharam em direção à Necrópole da Consolação, ostentando bandeiras da nação brasileira. O objetivo da romaria era o de homenagear os abolicionistas com visitas aos túmulos de Luis Gama e Antônio Bento, outra grande figura do abolicionismo na cidade de São Paulo (O CLARIM DA ALVORADA, 9 jun. 1929, p.5). Aqui podemos notar duas referências importantes no pensamento dos articulistas do Clarim da Alvorada, a presença dos símbolos nacionais e as honras aos abolicionistas que estavam associadas aos ideais de integração social do negro.

Dessa forma, os abolicionistas foram transformados em personagens de uma narrativa histórica que dava ao negro o papel de sujeito na história brasileira. ${ }^{3}$ Eles foram equiparados pelo Clarim da Alvorada a Henrique Dias, o negro que lutou contra os holandeses no período colonial; ao Quilombo dos Palmares, símbolo da bravura dos negros; e à Guerra do Paraguai, evento protagonizado pelos escravos soldados, para compor uma série de símbolos que, além de negros, seriam interpretados também como nacionais. Se levarmos em consideração que a consciência nacional é nada mais do que uma comunidade imaginada, ou seja, um conjunto de mitos, versões da História e emblemas que dão o sentido à ideia de coletividade a um grupo de "desconhecidos", o objetivo do Clarim da Alvorada era o de incluir narrativas e imagens "positivas" dos negros ao imaginário social brasileiro (ANDERSON, 2008).

Assim, mesmo que todo esse processo tenha envolvido o apelo por uma identidade negra, o jornal nunca sugeriu a preponderância de uma identidade racial sobre uma identidade nacional. Embora propusesse uma identidade negra, o que poderia ser interpretado como o surgimento de identidades fragmentadas dentro do contexto brasileiro, a intenção era a de afirmar a nacionalidade a partir do reconhecimento de sua negritude.

O que percebermos aqui é a força do movimento abolicionista no imaginário dos jornalistas do Clarim da Alvorada e dos ativistas do período. O Brasil imaginado por eles passava por uma série de construções concebidas ou reforçadas pelos próprios "apóstolos" do abolicionismo. A identidade negra que se revelava nas páginas do jornal esteve baseada em

${ }^{3}$ O Clarim da Alvorada não foi o único a se preocupar em escrever uma narrativa histórica nacional com heróis negros, outros periódicos como o carioca Kosmos, na primeira década do século XX, também repensou olugar do negro na história. (DANTAS, 2007). 
ideais de uma integração atribuídas a um pensamento abolicionista, exaltado com frequên cia pelo jornal:

Irmãos, é o hoje o dia que se comemora a data de libertação dos escravos, data em que foi extinta para sempre a escravidão negra no Brasil. Portanto, o dia do nosso incomensurável júbilo, da nossa alegria sem par, em que as fibras dos nossos corações se agitam, pulsando fortemente ante tantas manifestações. Em cada olhar nota-se a expressão de gratidão, em cada lábio de expressão do júbilo, e em cada peito percebese o arfar forte, dando-nos demonstração de orgulho. Este grandioso feito devemos a Antonio Bento, José do Patrocínio, Luis Gama e muitos outros que tudo fizeram para o engrandecimento da raça negra no Brasil.

Esses foram os nossos homens de ontem, foram os que não mediram sacrifícios, não pouparam esforços para a realização dos seus ideais, que são os nossos. Lutaram com intrepidez, com bravura, a fim de ver um dia de liberdade do negro cativo. A esses heroicos devemos render, no dia de hoje, os nossos dignos aplausos. Aplaudamos, pois, as homenagens, honrando seus nomes e feitos abolicionistas que coadjuvaram para a evolução da nossa raça. Irmãos, imitemo-los, a nossa classe necessita de homens, trabalhemos para que vejamos alto, bem alto a nossa classe. Unamo-nos, esforcemo-nos, estudemos para a melhora da raça. ( $O$ CLARIM DA ALVORADA, 13 maio 1927, p.1).

Nesse sentido, parte dos perfis de abolicionistas apresentados no Clarim da Alvorada eram construções idealizadas. Se por um lado Joaquim Nabuco, também recuperado pelo periódico, reconhecia o valor dos escravos enquanto a grande força da economia brasileira, por outro deixava transparecer a sua preocupação com a forte presença do elemento negro na sociedade brasileira. Sendo assim, nem todo o pensamento de Nabuco poderia ser apropriado pelos articulistas da pequena folha. No debate sobre a imigração de trabalhadores chineses para o Brasil, o abolicionista manifestou sua oposição à chegada de uma raça inferior em um país predominantemente africano. Em seus comentários sobre um "perigo amarelo" ecoavam as teorias racistas do século XIX que orientaram a formação das nações nas Américas. Assim, ao mesmo tempo em que lutava em favor da participação do negro na comunhão brasileira, Nabuco defendia a presença maior de uma "raça mais inteligente", que viria da Europa para colocar o Brasil nos trilhos do progresso (SKIDMORE, 1996; NABUCO, 1977). Ou seja, o Nabuco do Clarim da Alvorada era o que apoiava a participação efetiva do negro na sociedade brasileira, e não o que valorizava os trabalhadores imigrantes. 
Interessante também é observar que em meio a essa construção de um abolicionismo heroico nas páginas do Clarim da Alvorada emergiu a figura de Sílvio Romero, intelectual proeminente da Faculdade de Direito de Recife na segunda metade do século XIX. O que nos surpreende aqui é a seleção de Romero para compor o universo abolicionista no jornal, já que ele se indispôs com o movimento. $O$ intelectual via com maus olhos a presença do negro na formação da sociedade, embora reconhecesse o seu papel fundamental na história da economia brasileira. Romero estava na contramão do projeto de ascensão do negro do Clarim da Alvorada, já que defendia um futuro para a nação brasileira com a presença reduzida do elemento negro. $O$ intelectual acreditava que a miscigenação racial poderia ser uma solução para o progresso do país, o embranquecimento conduziria naturalmente a sociedade brasileira a um processo evolutivo (SCHWARCZ, 2007). Contudo, na leitura dos articulistas do Clarim da Alvorada somente os aspectos considerados positivos da visão do intelectual sergipano foram reforçados, reservando a ele um lugar na frente de defensores da "raça negra". Os editores do periódico negro foram perspicazes ao mobilizar uma memória do abolicionismo para reforçar o projeto integracionista do jornale de ativistas que gi ravam em torno de sua órbita.

Sendo assim, as figuras abolicionistas não apareceram nas páginas do jornal a partir de uma leitura que reproduzisse fidedignamente o pensamento dos "libertadores da raça", mas sim baseadas num abolicionismo imaginado e construído pelos articulistas que favorecia a incorporação simbólica do negro à sociedade brasileira. Os textos que elogiavam a bravura dos abolicionistas foram utilizados como inspiração para a rearticulação de lideranças negras no pós-abolição. O Clarim da Alvorada se apropriou de uma série de simbologias construídas pelo abolicionismo, idealizando alguns nomes e reinterpretando os seus discursos para fazer uma análise crítica da situação dos negros no Brasil e estruturar narrativas de uma fraternidade racial brasileira, tratando a geração de ativistas negros como Jaime de Aguiar, José Correia Leite, Lino Guedes e Arlindo Veiga do Santos como agentes de um novo abolicionismo.

\section{Um símbolo para a nação: a Mãe Preta}

Outro feito do Clarim da Alvorada no sentido de se construir uma identidade, ao mesmo tempo negra e brasileira, foi a exaltação da imagem da Mãe Preta, sempre reforçando a 
importância dos negros na constituição da nação brasileira e incluindo-os como agentes importantes da identidade nacional. A ideia veio à tona após a circulação da informação de que jornalistas do Rio de Janeiro planejavam fazer um pedido ao prefeito para que se mandasse erigir um monumento à Mãe Preta. $\mathrm{O}$ movimento foi amplamente divulgado pelo jornal $A$ Notícia que, na figura de Cândido Campos, procurava atrair diferentes segmentos da sociedade carioca. A intenção da homenagem era, justamente, a de afirmar a vocação da nação brasileira para a mistura "racial", confrontando qualquer argumento que tivesse relação com as teorias raciais que condenavam a população negra à inferioridade. (SIEGEL, 2007).

Na edição de abril de 1926 do Clarim da Alvorada, Moisés Cintra, colaborador do jornal, sugeriu que os negros paulistanos seguissem o exemplo dos cariocas que tinham a pretensão de homenagear heróis e símbolos da "raça negra". A Mãe Preta surgiu então como a personagem ideal, pois representaria todas as mulheres que haviam trabalhado como escravas, amamentado os filhos dos senhores. O monumento seria a expressão de gratidão da "atual" geração àquelas que haviam ajudado a erguer a nação brasileira. A Mãe Preta era uma proposta que englobava a reivindicação de inclusão dos negros na sociedade, o reconhecimento do seu papel na História do país e a congregação de negros e brancos sob a égide da bandeira nacional.

\begin{abstract}
Veremos nesse grande monumento representado o maior dos sentimentos humanos que nosso tão caro Brasil deve aos seus primeiros obreiros, a aqueles que de sol em sol, com o seu próprio sangue, resignados labutaram para o seu atual projeto; e da Mão Preta jamais nós nos olvidaremos dos seus grandes sacrifícios, dos seus afetos, dos seus carinhos, lembraremos sempre dos seus inúmeros trabalhos em prol dos seus filhos que vão destas a gerações de amanhã, sempre com inúmeras glórias e elevada grandeza. Eis uma homenagem sincera, a maior por certo, que o Brasil deve prestar em sinal de uma verdadeira gratidão. ( $O$ CLARIM DA ALVORADA, 25 abr. 1926, p.1).
\end{abstract}

Motivados pela riqueza do símbolo, logo os jornalistas seriam tomados pela iniciativa de homenagear a Mãe Preta e a "raça negra". Já na edição de julho do mesmo ano, Jaime de Aguiar lançava uma ofensiva contra os "tradicionais negros detratores" que sempre criticavam as ideias de valorização do negro brasileiro. Para ele, assim como as instituições de ajuda e a Confederação dos Homens de $\operatorname{Cor}^{4}$, o monumento à Mãe Preta seria uma "grande obra" que ajudaria o negro a retomar o caminho do progresso (O CLARIM DA ALVORADA, 20 jun. 1926, p.1).

\footnotetext{
${ }^{4}$ Na década de 1920, O Clarim da Alvorada também aventou a ideia de criar uma instituição que coordenasse a articulação entre os clubes negros da cidade com intuito de desenvolver programas de ajuda a população negra.
} 
Além de representar uma comunhão racial entre as diversas "raças" brasileiras, a Mãe Preta simbolizaria a retomada de alguns dos valores que os negros haviam perdido ao longo do período pós-abolição.

Na edição de maio de 1927, o Clarim da Alvorada, ao invés de trazer na sua primeira página o editorial e os artigos impressos nas habituais três colunas, publicou um texto em homenagem à Mãe Preta diagramado em forma de "13 de maio". Saul de Navarro afirmava que a civilização brasileira tinha origem na figura da Mãe Preta. Usando um texto carregado de metáforas, ele retornou ao período em que as escravas alimentavam os seus próprios filhos e os de seus senhores. Navarro também relembrou os leitores que sua geração ainda havia conhecido a grandeza maternal e "capacidade cristã de sacrifício" dessa querida figura dos tempos da escravidão. Dentre os filhos ilustres da Mãe Preta, Navarro citou o abolicionista Joaquim Nabuco, que havia entrado em contato com o mundo escravocrata nos engenhos de Recife.

O Brasil, um gigante que hoje vive a vertigem de sua civilização de suas energias, cresceu ao calor do teu carinho, ouvindo o teu idioma de ternura humana, que não fala senão pelas lágrimas e pelos sorrisos, $\mathrm{e}$ tudo expressa num olhar, numa bênção e num gemido. O Brasil gigantesco foi acalentado no teu colo, bebeu a seiva de seus seios opulentos, tu o criaste. Sim, do teu seio noturno de escrava e mártir, de mãe por instinto e pelo devotamento, bebemos o leite puríssimo, que nos foi alimentado para o organismo e para a alma, porque desse leite generosamente dado dimana nossa bondade, que nos singulariza como raça afetiva, que tem o dom do agrado e a virtude suprema do perdão. ( $O$ CLARIM DA ALVORADA, 13 maio 1927, p.1).

A campanha pelo monumento à Mãe Preta nos revela o modo como os jornalistas do Clarim da Alvorada pensavam a "integração negra" à sociedade brasileira. O texto de Navarro deixa bem claro que a opção do jornal e dos ativistas negros daquele período era pela inclusão do negro como parte importante da identidade nacional. A simbologia da Mãe Preta, embora remetesse os leitores ao período da escravidão, estabelecia uma origem comum para negros e brancos, apontando para uma origem da sociedade brasileira que transcendia as diferenças "raciais". Assim como alimentava a sua prole, a Mãe Preta também oferecia os seus seios para os filhos de seus senhores, definindo uma fraternidade entre negros e brancos. 
Nesse sentido, os cidadãos negros poderiam estabelecer laços com figuras como a de Joaquim Nabuco. O espaço do engenho, seja em uma cidade de Pernambuco - onde o abolicionista foi educado - ou em qualquer outra parte do Brasil, tornava-se elemento fundamental desse imaginário. Ainda que as experiências dos escravos estivessem associadas ao sentimento de sofrimento, a noção de maternidade que o símbolo evocava satisfazia a pretensão dos jornalistas do Clarim da Alvorada de conceber uma identidade nacional que atravessasse as fronteiras "raciais" da sociedade brasileira.

Como demonstra a historiadora Micol Siegel (2007), a imagem da Mãe Preta, enquanto representante da harmonia das relações entre negros e brancos, circulava também entre a elite brasileira, o que permitia o diálogo das lideranças negras com intelectuais e políticos que demonstravam interesse na elaboração da noção de "fraternidade racial" no Brasil. Contudo, a Mãe Preta era introduzida em um outro contexto. Se nas narrativas do engenho ela representava a relação próxima entre negros e brancos no Brasil a partir de uma estrutura hierárquica extremamente rígida, nas páginas do Clarim da Alvorada ela estava associada a um projeto de mobilidade social que previa justamente a flexibilização de barreiras raciais concebidas no sistema escravocrata.

Em um curto período de tempo, a imagem da Mãe Preta foi associada ao dia 28 de setembro, o da comemoração da Lei do Ventre Livre. As edições de maio e de setembro eram dedicadas ao movimento abolicionista. Na edição de setembro de 1928, o editorial do jornal especulou sobre a possibilidade de se criar o dia da Mãe Preta, justamente no dia 28 do mês. Na primeira página, em meio a o texto, o Clarim da Alvorada estampava o desenho de uma mulher negra com uma criança branca em seu colo e uma criança negra em pé ao seu lado, fazendo, talvez, alusão ao sacrifício das mães escravas que passavam maior tempo cuidando dos filhos dos senhores ao invés de se dedicar aos seus. Nessa edição, o jornal evocou uma série de imagens nos textos e nas ilustrações que passariam a ser associadas à Mãe Preta: a escrava amamentando os filhos do senhor, cantando música de ninar para adormecer as crianças ou contando histórias (O CLARIM DA ALVORADA, 28 set. 1928, p.1).

Figura 2- Imagem da Mãe Preta 


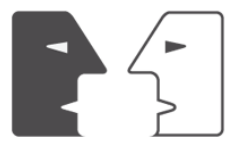

ANTÍTESES

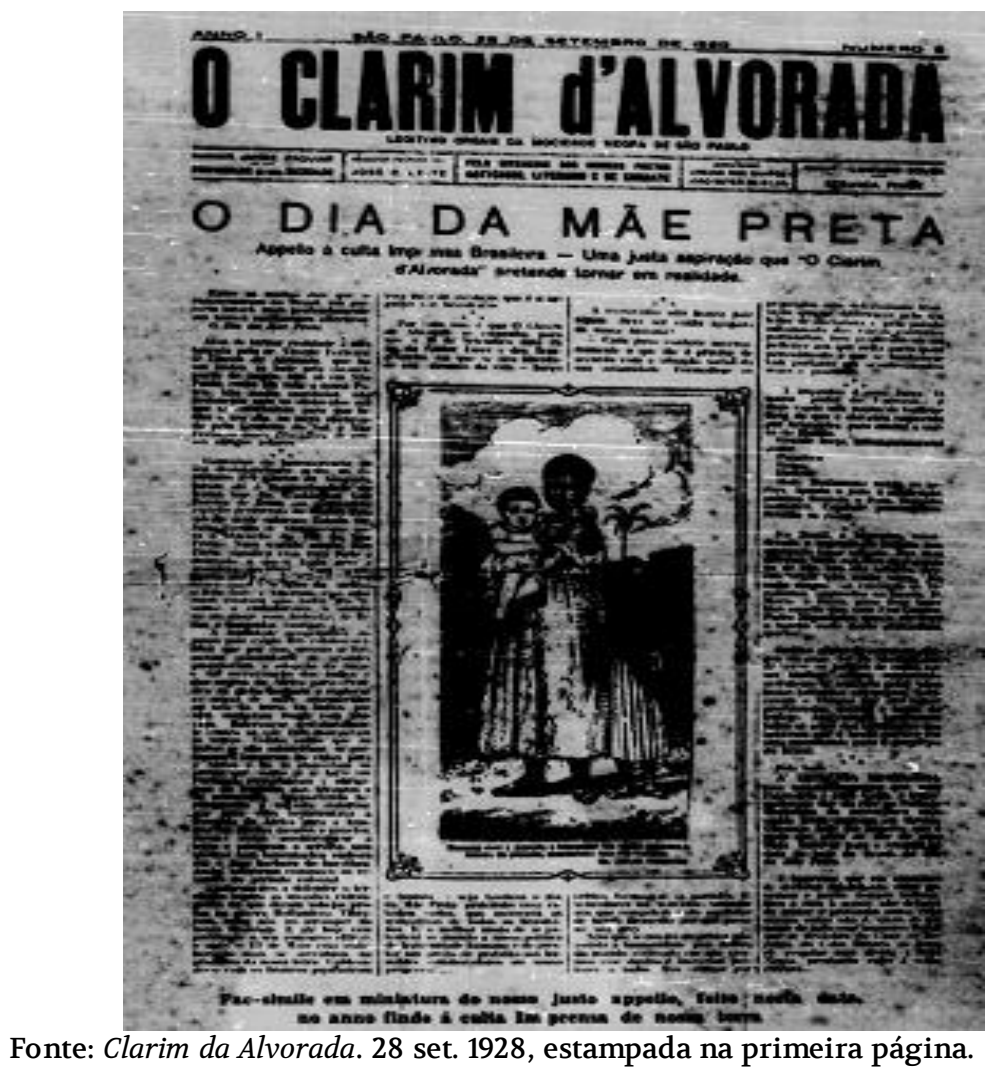

A Mãe Preta foi proposta pelo Clarim da Alvorada como um símbolo da fundação da nação brasileira, a agente de promoção da mistura entre as "raças" do Brasil, que deveria ser compartilhada por toda a sociedade. Nos Estados Unidos, a versão ianque da Mãe Preta - a Mammy - foi refutada pelos negros norte-americanos. A representação da mulher negra que cuidava dos filhos dos senhores foi lida como símbolo de submissão negra frente à escravidão, elemento de uma ideologia racista e paternalista que idealizava uma sociedade extremamente racializada (RITTERHOUSE, 2006; SIEGEL, 2007). No Brasil, a ideia de uma nação formada pelas três raças é retomada pelo periódico em nome de um projeto de ascensão para toda a população negra. Conforme assinala Antônio Sérgio Guimarães (2004), a ideia de democracia racial não foi gestada somente pelos intelectuais brancos. Os intelectuais negros, na década de 1920 e 30, a endossaram para fazer firmar os seus interesses de integração social. 
No projeto editorial do Clarim da Alvorada, é possível identificar duas abordagens. Na primeira delas, o periódico acenava para os seus leitores e para a população negra em geral, urgindo por uma identidade negra baseada em uma solidariedade que atravessaria as diferenças sociais entre os negros. Estes deveriam se articular politicamente em torno de um novo abolicionismo, ou a retomada de um abolicionismo incompleto, combatendo o preconceito de cor e elaborando a imagem de um negro moderno.

Por outro lado, o jornal se preocupava em demonstrar a face brasileira dos feitos da população negra. $O$ argumento era o de que a sociedade não poderia fechar os seus olhos para a contribuição dos milhões de africanos que haviam trabalhado, sem ganhar nada em troca, para o progresso da nação. A Mãe Preta, nesse sentido, revelaria uma "essência brasileira" que estaria ligada profundamente às experiências negras; falar de Brasil sem se referir a ela era como negar a sua própria natureza.

A tendência assimilacionista das lideranças negras desse período não pode ser confundida com a leitura que parte da elite brasileira passou a fazer de símbolos de fraternidade racial no Brasil. A compreensão do Clarim da Alvorada sobre o abolicionismo e a Mãe Preta está associada ao enquadramento da população negra a um contexto histórico diverso do da escravidão. Ainda que esses símbolos pudessem ser usados de forma conservadora por alguns políticos, visando diluir as tensões causadas pelas relações permeadas pelas noções de "raça", a preocupação de José Correia Leite e os demais articulistas do periódico negro era a de promover a mobilidade social. Enquanto a Mãe Preta possibilitava a congregação "racial", as imagens dos abolicionistas embasavam um discurso direto sobre ascensão do negro, imaginando um projeto abolicionista para confrontar o processo de “degradação" da população negra.

\section{Referências}

ALBUQUERQUE, Wlamyra R. de. O jogo da dissimulação: abolição e cidadania negra no Brasil. São Paulo: Companhia das Letras, 2009.

ANDERSON, Benedict. Comunidades Imaginadas: reflexões sobre a origem e a difusão do nacionalismo. São Paulo: Companhia das Letras, 2008.

ANDREWS, George Reid. Negros e Brancos em São Paulo, 1888-1988. Bauru: EDUSC, 1998. 
AZEVEDO, Célia Maria Marinho de. Abolicionismo, Estados Unidos e Brasil: uma história comparada (século XIX). São Paulo: Annablume, 2003.

BASTIDE, Roger. Estudos afro-brasileiros. São Paulo: Editora Perspectiva, 1973.

BUTLER, Kim D. Freedoms given, freedoms won: Afro-Brazilian in post- abolition, São Paulo and Salvador. New Brunswick: Rutgers University Press, 1998.

CHALHOUB, Sidney. Trabalho, lar e botequim. Campinas: Editora Unicamp, 2005.

DANTAS, Carolina Vianna. Cultura histórica, República e o lugar dos descendentes de africanos na nação. In: ABREU, Martha; SOIHET, Rachel; GONTIJO, Rebeca. Cultura política e leituras do passado: historiografia e ensino de história. Rio de Janeiro: Civilização Brasileira, 2007.

DAVILA, Jerry. Diploma de brancura: política social e racial no Brasil - 1917-1945. São Paulo: UNESP, 2006.

DOMINGUES, Petrônio José. Uma história não contada: negro, racismo e branqueamento no São Paulo pós-abolição. São Paulo: Senac, 2004.

FERNANDES, Florestan. A integração do negro na sociedade de classes. São Paulo: Editora Globo, 2008. v. 1.

FERRARA, Miriam Nicolau. A imprensa negra paulista (1915-1963). São Paulo: FFLCH/USP, 1986. GUIMARÃES, Antônio Sérgio Alfredo. Intelectuais negros e formas de integração nacional Revista Estudos Avançados, São Paulo, v.18, n.50, p. 271-284, 2004.

JACINO, Ramatis. O negro no mercado de trabalho em São Paulo, pós-abolição (1912-1920). 2012. Tese (Doutorado em Historia) - Universidade de São Paulo, São Paulo.

JUCÁ, Joselice. André Rebouças: reforma \& utopia no contexto do Segundo Império: quem possui a terra possui o homem. Rio de Janeiro: Odebrecht, 2001.

MACHADO, Maria Helena P. T. O Plano e o Pânico: os movimentos sociais na década da Abolição. São Paulo: EDUSP, 2010.

NABUCO, Joaquim. O Abolicionismo. Petrópolis: Vozes, 1977.

PEREIRA, Matheus Serva. Uma viagem possível: da escravidão à cidadania. Quintino de Lacerda e as possibilidades de integração dos ex-escravos no Brasil. 2011. Dissertação (Mestrado em História) - Universidade Federal Fluminense, Niterói. 
RITTERHOUSE, Jennifer. Growing up Jim Crow: how black and white southern children learned race. Chapel Hill: University of North Carolina Press, 2006.

SCHWARCZ, Lilia Moritz. O espetáculo das raças: cientistas, instituições e questão racial no Brasil 1870-1930. São Paulo: Companhia das Letras, 2007.

SKIDMORE, Thomas E. Preto no Branco: raça e nacionalidade no pensamento brasileiro. Rio de Janeiro: Paz e Terra, 1996.

SIEGEL, Micol. "Mães pretas, filhos cidadãos". In: CUNHA, Olívia Maria Gomes da \& GOMES, Flávio dos Santos. Quase cidadão: histórias e antropologias da pós-emancipação no Brasil. Rio de Janeiro: Editora FGV, 2007.

Recebido em 13/10/2016

Aprovado em 13/01/2017 